\title{
Consciousness Energy Healing Treatment: Phys- icochemical and Thermal Characterization of Magnesium
}

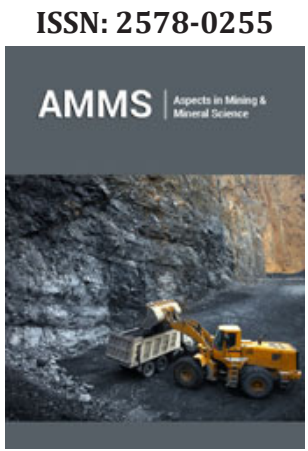

*Corresponding author: Snehasis Jana, Trivedi Science Research Laboratory Pvt Ltd, Thane (W), Maharashtra, India

Submission: 盟 May 09, 2019

Published: 監May 31, 2019

Volume 3 - Issue 1

How to cite this article: Trivedi $D$, Trivedi MK, Branton A, Nayak G, Jana S. Consciousness Energy Healing Treatment: Physicochemical and Thermal Characterization of Magnesium. Aspects Min Miner Sci.3(1). AMMS.000552.2019. DOI: 10.31031/AMMS.2019.03.000552.

Copyright@ Dahryn Trivedi, This article is distributed under the terms of the Creative Commons Attribution 4.0 International License, which permits unrestricted use and redistribution provided that the original author and source are credited.

\author{
Trivedi $\mathrm{D}^{1}$, Trivedi $\mathrm{MK}^{1}$, Branton $\mathrm{A}^{1}$, Nayak $\mathrm{G}^{1}$, Jana $\mathrm{S}^{2 *}$ \\ ${ }^{1}$ Trivedi Global Inc Henderson, USA \\ ${ }^{2}$ Trivedi Science Research Laboratory Pvt Ltd, India
}

\begin{abstract}
Magnesium is the fourth most common human body mineral followed by sodium, potassium, and calcium and it acts as a cofactor in more than 300 enzyme system. The aim of this study was to determine the influence of the Trivedi Effect ${ }^{\circledR}$-Consciousness Energy Healing Treatment on the physicochemical and thermal properties of magnesium by using sophisticated analytical techniques. The test sample was divided into the control and treated magnesium; where the Trivedi Effect ${ }^{\circledR}$-Consciousness Energy Healing Treatment was provided remotely only to the treated part by a renowned Biofield Energy Healer, Dahryn Trivedi; however, the control part was not received the Biofield Energy Treatment. The particle sizes of the treated magnesium were significantly increased by $45.92 \%\left(\mathrm{~d}_{10}\right), 31.07 \%\left(\mathrm{~d}_{50}\right), 21.44 \%\left(\mathrm{~d}_{90}\right)$, and $28.74 \%\{\mathrm{D}(4,3)\}$ compared to the control sample. Therefore, the resultant specific surface area of the treated magnesium was significantly reduced by $28.57 \%$ than the control sample. The powder X-ray diffraction peak intensities and crystallite sizes of the treated magnesium were decreased ranging from $0.72 \%$ to $11.43 \%$ and $3.81 \%$ to $19.40 \%$, respectively, compared to the control sample. The average crystallite size of the treated magnesium was significantly reduced by $13.39 \%$, compared with the control sample. The weight loss of the treated magnesium was increased by $79.09 \%$ during the thermal degradation; however, the residue amount was decreased by $40.31 \%$ as compared to the control sample. The maximum thermal degradation temperature of the treated magnesium was reduced by $4.95 \%$, compared to the control sample. Hence, the Trivedi Effect ${ }^{\circledR}$-Consciousness Energy Healing Treatment might alter the physicochemical and thermal properties of magnesium by forming a new polymorph that may show better appearance, flowability, and compatibility along with altered thermal stability compared to the control sample. Thus, the Trivedi Effect ${ }^{\circledR}$-Consciousness Energy Healing Treated magnesium could be used efficiently in designing the more efficacious novel nutraceutical formulations against various diseases such as muscle cramps and spasm, gestational deficiency in pregnancy, migraine, kidney disease, diabetes, and heart diseases, etc.
\end{abstract}

Keywords: Magnesium; Consciousness energy healing treatment; The Trivedi Effect ${ }^{\circledR}$; PSA; PXRD; TGA/ DTG

Abbreviations: ATP: Adenosine Triphosphate; ADP: Adenosine Diphosphate; NCCAM: National Center for Complementary and Alternative Medicine; PXRD: Powder X-ray Diffraction; PSA: Particle Size Analysis; TGA: Thermal gravimetric analysis; DTG: Differential thermogravimetric analysis

\section{Introduction}

Nutritional deficiency is increasing due to many reasons such as a neglected epidemic of chronic disease and another important is the widespread deficiency of selected nutrients. Among which, magnesium deficiency and the importance of this element in the human organism is well defined [1]. Thus, biological significance in day-to-day life has clinical relevance, as magnesium is the fourth most common human body mineral followed by sodium, potassium, and calcium [2]. On an average, an adult required approximately 25 grams of magnesium in reserve with its distribution in bone (53\%), muscles (27\%), soft tissues $(19 \%)$, and less than $1 \%$ in the serum. Serum concentration ranges from $75-95 \mathrm{mmol} / \mathrm{L}$ and below would be considered as deficient $[3,4]$. The major biological significance of magnesium is its involvement as a cofactor in more than 300 enzyme system. This is required for various biological fundamental processes including energy production and nucleic acid synthesis. Mitochondria stores the high level of intracellular magnesium, which plays an important role in inorganic phosphate synthesis and ATP (adenosine triphosphate) from ADP (adenosine diphosphate) synthesis. More than 3000 human proteins bind with magnesium along with 
ATP to yield a bioactive form of ATP, ie., Mg-ATP.. The biological half-life of magnesium is about 42 days ( 1000 hours) [5]. The metabolic role of magnesium and its important functioning in body homeostasis has been significantly reported. Besides, deficiency of magnesium may lead to many physical and mental health issues. Magnesium sulfate (MgS) has reported several benefits and significant improvement in the symptom of breathlessness in many acute asthma exacerbations [6,7]. Magnesium has a significant role in vitamin D absorption and role in rickets and osteoporosis; it is required for conversion of vitamin $\mathrm{D}$ into its active form needed for calcium absorption and metabolism, along with the functioning of parathyroid hormone [8]. Magnesium has a high role in muscle cramps and spasm [9], gestational deficiency in pregnancy with lower mean arterial pressure in women along with higher birth weight infants $[10,11]$, importance in migraine [12], in prevention of diabetic complications [13], depression [14], kidney disease, and heart diseases and many more has been significantly studied. Some ideal natural sources of magnesium are hemp seeds, pumpkin seeds, flax seeds, and Brazil nuts. Besides, some carbohydrates which include a high content of magnesium are whole wheat bread, baked potato, rice, brown rice, kidney beans, and white rice. In addition, milk products and green leafy vegetables such as boiled spinach, avocado, and chopped broccoli are the other rich source of magnesium [15].

The physicochemical and thermal properties of compounds play important role in their formulation development and the Consciousness Energy Healing Treatment is a novel approach that have been used these days in modifying such properties of compounds [16,17]. The Biofield Energy Treatment is a kind of Energy therapy (the Trivedi Effect ${ }^{\circledR}$ ) and the use of such therapies against various diseases has been evident nowadays due to their advantageous effect. Therefore, such therapies are also accepted by the National Center for Complementary and Alternative Medicine (NCCAM) under the category of Complementary and Alternative Medicine (CAM) therapies along with yoga, Reiki, Ayurvedic medicine, homeopathy, Qi Gong, Tai Chi, chiropractic/osteopathic manipulation, acupuncture, acupressure, hypnotherapy, aromatherapy, cranial sacral therapy, etc. $[18,19]$. Similarly, the importance of the Trivedi Effect ${ }^{\circledR}$-Consciousness Energy Healing Treatment has been reported by various researchers for its significant impact on the living organisms and non-living materials. The impact of the Biofield Energy Treatment has been significantly improved the agricultural productivity [20,21], antimicrobial activity [22-24], physicochemical properties of the pharmaceuticals / nutraceuticals [25-27], various properties of metals, ceramics, and chemicals [28-30], and in the field of biotechnology [31,32], skin and bone health [33-35], and cancer research [36], etc. Thus, this research work was designed to determine the effect of the Biofield Energy Treatment (the Trivedi Effect ${ }^{\circledR}$ ) on the physicochemical and thermal characteristics of magnesium by using various analytical techniques.

\section{Materials and Methods}

\section{Chemicals and reagents}

The test sample magnesium powder (MEPCO, India) and other chemicals used during the experiments were purchased from India.

\section{Consciousness energy healing treatment strategies}

The experimental design includes dividing the test sample magnesium into two parts, among which the first part was not received the Biofield Energy Treatment and considered as the control sample. Besides, the second part of the sample was received the Trivedi Effect ${ }^{\circledR}$-Consciousness Energy Healing Treatment for about 3 minutes under standard laboratory conditions and known as The Biofield Energy Treated magnesium. This treatment was provided to the test sample, remotely, by the renowned Biofield Energy Healer, Dahryn, USA, through her unique energy transmission process. However, the control sample was treated by a "sham" healer, who did not have any awareness about the Biofield Energy. Both the samples were then stored in sealed conditions and characterized further by using modern analytical techniques.

\section{Characterization}

The particle size distribution (PSD) analysis of magnesium test samples were performed with the help of Malvern Mastersizer 2000 (UK) using the wet method $[37,38]$. The powder X-ray diffraction (PXRD) analysis of magnesium powder samples were performed with the help of Rigaku MiniFlex-II Desktop X-ray diffractometer (Japan) $[39,40]$. The average size of crystallites was calculated from PXRD data using the Scherrer's formula (1)

$$
\mathrm{G}=\mathrm{k} \lambda / \beta \cos \theta
$$

Where $\mathrm{G}$ is the crystallite size in $\mathrm{nm}$, $\mathrm{k}$ is the equipment constant, $\lambda$ is the radiation wavelength, $\beta$ is the full width at half maximum, and $\theta$ is the Bragg angle [41]. Similarly, the thermal gravimetric analysis (TGA) thermograms of magnesium samples were obtained with the help of TGA Q50 TA instruments [42].

The $\%$ change in particle size, surface area, crystallite size, peak intensity, weight loss and maximum thermal degradation temperature of the Biofield Energy Treated magnesium was calculated compared with the control sample using the following equation 2:

$$
\% \text { change }=[(\text { Treated-Control }) / \text { Control }] \times 100
$$

\section{Results and Discussion}

\section{Particle size analysis (PSA)}

Table 1: The particle size distribution of the control and treated magnesium.

\begin{tabular}{|c|c|c|c|c|c|}
\hline Parameter & $\mathbf{d}_{\mathbf{1 0}}(\boldsymbol{\mu m})$ & $\mathbf{d}_{\mathbf{5 0}}(\boldsymbol{\mu m})$ & $\mathbf{d}_{\mathbf{9 0}}(\boldsymbol{\mu m})$ & $\mathbf{D}(\mathbf{4}, \mathbf{3})(\boldsymbol{\mu m})$ & $\mathbf{S S A}\left(\mathbf{m}^{\mathbf{2}} / \mathbf{g}\right)$ \\
\hline Control & 176.31 & 344.02 & 626.33 & 375.28 & 0.021 \\
\hline
\end{tabular}




\begin{tabular}{|c|c|c|c|c|c|}
\hline Biofield Energy Treated & 257.28 & 450.89 & 760.63 & 483.12 & 0.015 \\
\hline Percent change (\%) & 45.92 & 31.07 & 21.44 & 28.74 & -28.57 \\
\hline
\end{tabular}

$d_{10}, d_{50}$, and $d_{90}$ : particle diameter corresponding to $10 \%, 50 \%$, and $90 \%$ of the cumulative distribution, $D(4,3)$ : the average mass-volume diameter, and SSA: the specific surface area.

The particle size analysis of both the control and treated samples of magnesium was done and presented in (Table 1). The results helped to determine the impact of the Biofield Energy Treatment on the particle size distribution of the sample. The treated magnesium showed a significant increase in the particle size values at $d_{10}(45.92 \%), d_{50}(31.07 \%), d_{90}(21.44 \%)$, and $D(4,3)$ (28.74\%), compared to the control sample (Table 1). Besides, the treated magnesium showed a significant reduction in the specific surface area by $28.57 \%$ that resulted due to the increase in the particle size values after the Biofield Energy Treatment, compared to the control sample.

Some previous studies suggested the increase in particle sizes of a compound due to the impact of the increase in thermal energy. Thus, it is presumed that the Biofield Energy Treatment might help in increasing the thermal energy within the molecules of sample, thereby decreasing the nucleus densities and resulted in enhanced particle size $[43,44]$. Such an increased particle size of the treated magnesium might enhance the shape, appearance, and flowability of the treated magnesium as compared to the control sample $[45,46]$.

\section{Powder X-ray Diffraction (PXRD) Analysis}

The PXRD diffractograms of both the samples were shown in (Figure 1). The diffractograms were further analyzed in terms of the variations observed in the Bragg's angles of the characteristic peaks of the treated magnesium along with the corresponding relative intensities and crystallite sizes, compared to the control sample (Table 2).

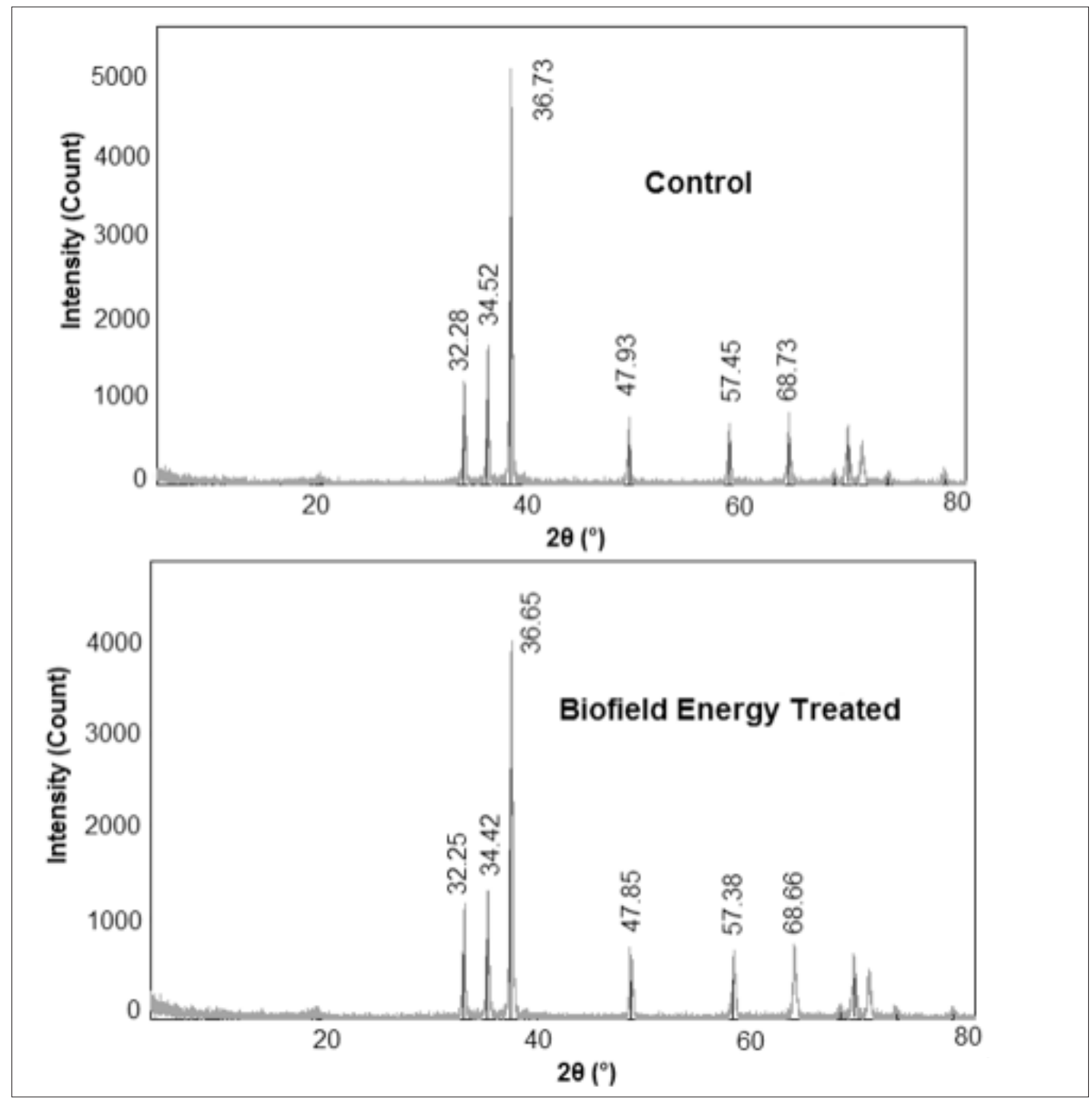

Figure 1: PXRD diffractograms of the control and treated magnesium. 
Table 2: PXRD data for the control and treated magnesium.

\begin{tabular}{|c|c|c|c|c|c|c|c|c|}
\hline \multirow[b]{2}{*}{ Entry No. } & \multicolumn{2}{|c|}{ Bragg angle $\left({ }^{\circ} 2 \theta\right)$} & \multicolumn{3}{|c|}{ Intensity (cps) } & \multicolumn{3}{|c|}{ Crystallite size (G, nm) } \\
\hline & Control & Treated & Control & Treated & $\%$ change $^{a}$ & Control & Treated & $\%$ change $^{b}$ \\
\hline 1 & 32.28 & 32.25 & 245 & 217 & -11.43 & 372 & 318 & -14.52 \\
\hline 2 & 34.52 & 34.42 & 283 & 265 & -6.36 & 381 & 327 & -14.17 \\
\hline 3 & 36.73 & 36.65 & 971 & 898 & -7.52 & 365 & 309 & -15.34 \\
\hline 4 & 47.93 & 47.85 & 139 & 138 & -0.72 & 366 & 295 & -19.4 \\
\hline 5 & 57.45 & 57.38 & 161 & 144 & -10.56 & 363 & 318 & -12.4 \\
\hline 6 & 68.73 & 68.66 & 168 & 158 & -5.95 & 341 & 328 & -3.81 \\
\hline
\end{tabular}

${ }^{a}$ denotes the percentage change in the intensity of the treated magnesium with respect to the control sample; ${ }^{b}$ denotes the percentage change in the crystallite size of the treated magnesium with respect to the control sample.

There was the presence of sharp and intense peaks in the diffractograms of the control and treated magnesium that showed the crystalline nature of both the samples. The peak intensities and crystallite sizes of the peaks of the treated magnesium showed significant changes as, the peak intensities were reduced ranging from $0.72 \%$ to $11.43 \%$; while the crystallite sizes were reduced ranging from $3.81 \%$ to $19.40 \%$, compared to the control sample. The impact of the Biofield Energy Treatment was also visible on the average crystallite size of the treated magnesium $(315.83 \mathrm{~nm})$ that was significantly reduced by $13.39 \%$ as compared to the control sample $(364.67 \mathrm{~nm})$. The altered peak intensities and crystallite sizes of the treated magnesium suggested the possibility of the formation of new polymorph after the Biofield Energy Treatment [47]. Such altered polymorphic properties of treated magnesium sample may suggest better solubility and bioavailability profile [48] as compared to the control sample.

\section{Thermal gravimetric analysis (TGA)/ Differential thermogravimetric analysis (DTG)}

The effect of the Biofield Energy Treatment on the thermal properties of magnesium sample was analyzed. The TGA thermograms of both the samples were recorded (Figure 2) and the data regarding the weight loss and residue weight were analyzed (Table 3). The results showed the significant increase in the total weight loss of the treated magnesium by $79.09 \%$ during the thermal degradation process; whereas, the residue weight was significantly reduced by $40.31 \%$ (Table 3 ) as compared to the control sample. Thus, the TGA data indicated a significant increase in the thermal degradation of the treated magnesium, compared to the control sample.

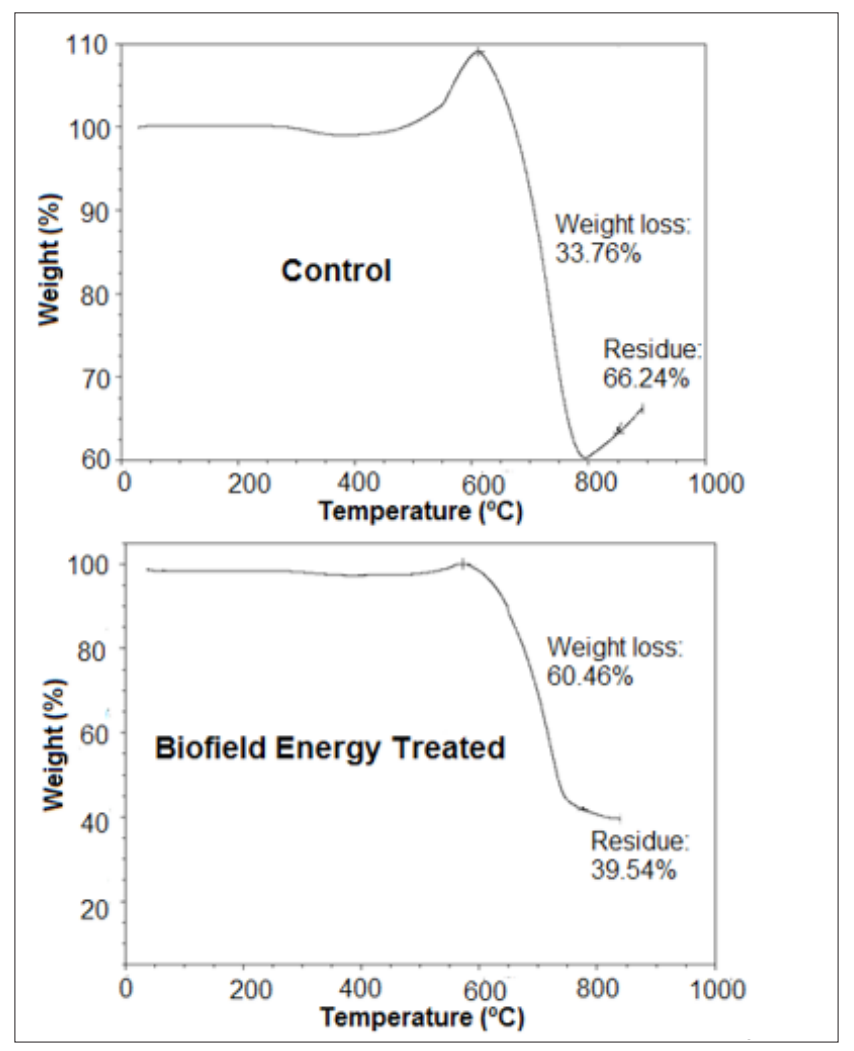

Figure 2: TGA thermograms of the control and treated magnesium. 
Table 3: TGA/DTG data of the control and treated samples of magnesium.

\begin{tabular}{|c|c|c|c|}
\hline \multirow{2}{*}{ Sample } & \multicolumn{2}{|c|}{ TGA } & DTG \\
\cline { 2 - 4 } & Total weight loss (\%) & Residue \% & T $\left._{\text {max }}{ }^{\circ}{ }^{\circ} \mathbf{C}\right)$ \\
\hline Control & 33.76 & 66.24 & 754.48 \\
\hline Biofield Energy Treated & 60.46 & 39.54 & 717.13 \\
\hline \% Change & 79.09 & -40.31 & -4.95 \\
\hline
\end{tabular}

$\mathrm{T}_{\max }=$ the temperature at which maximum weight loss takes place in TG or peak temperature in DTG.

Besides, the DTG analysis of both the samples showed the presence of a single peak in their respective thermograms (Figure 3) that denote the maximum thermal degradation temperatures $\left(\mathrm{T}_{\max }\right)$. The $\mathrm{T}_{\max }$ of the treated magnesium was found to be reduced by $4.95 \%$ than the $\mathrm{T}_{\max }$ of the control sample. Thus, the DTG data was observed in support of the TGA results, as the reduction in
$\mathrm{T}_{\max }$ temperature indicated the reduced thermal stability of the treated magnesium in comparison to the control sample. Overall, the TGA/DTG data indicated the increased thermal degradation of the treated magnesium after the Biofield Energy Treatment than the control sample.

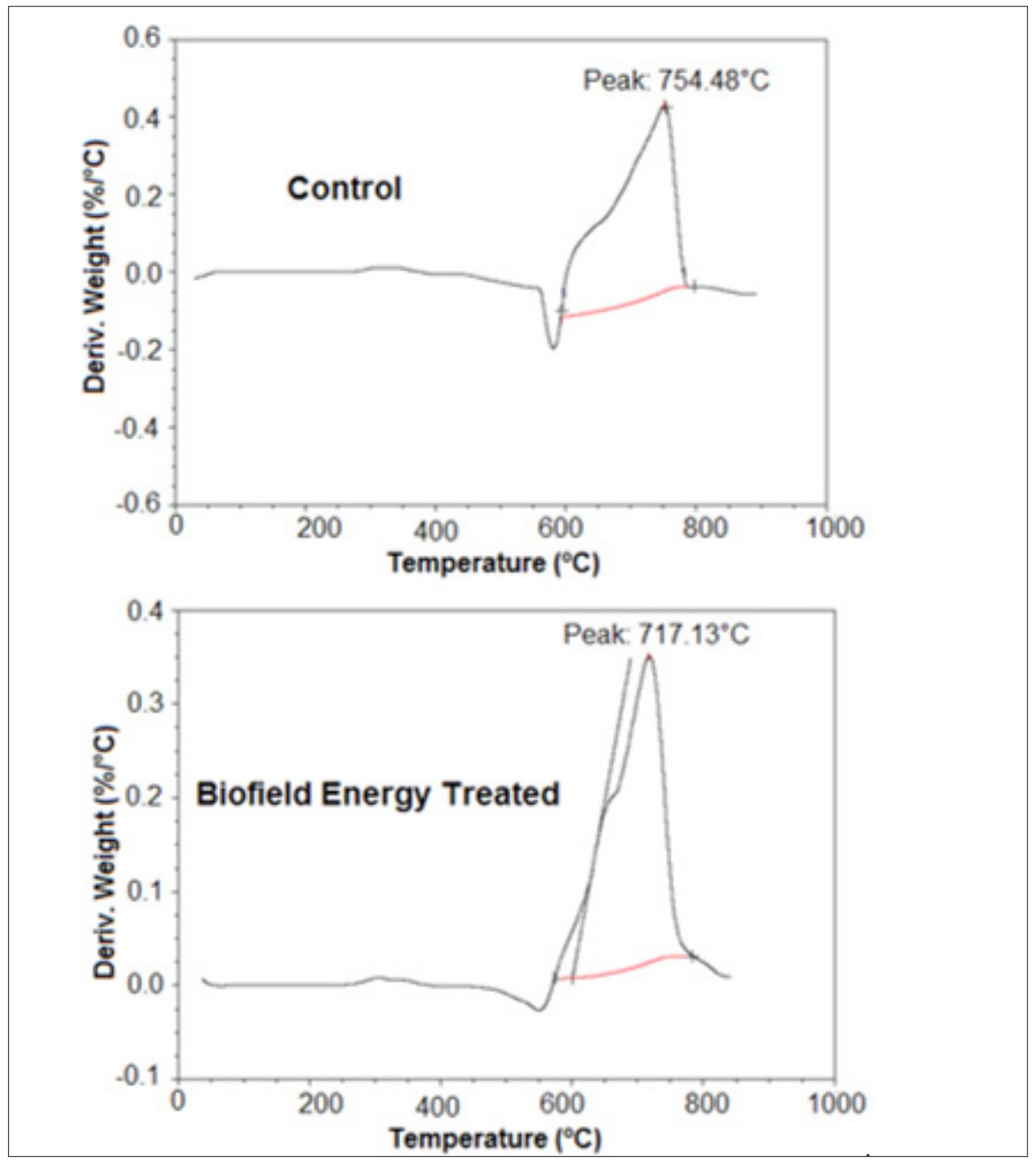

Figure 3: DTG thermograms of the control and Biofield Energy Treated magnesium.

\section{Conclusion}

The study sums up the impact of the Trivedi Effect ${ }^{\circledR}$ Consciousness Energy Healing Treatment on the physicochemical and thermal properties of magnesium. The particle sizes of the Biofield Energy Treated magnesium was significantly increased by $45.92 \%\left(d_{10}\right), 31.07 \%\left(d_{50}\right), 21.44 \%\left(d_{90}\right)$, and $28.74 \%\{D(4,3)\}$ compared to the control sample. Therefore, the resultant specific surface area of the Biofield Energy Treated magnesium was significantly reduced by $28.57 \%$ than the control sample. Such changes in the particle sizes and surface area of the treated magnesium might help in improving the appearance, flowability, shape, and compatibility of the sample, compared to the control sample. The powder X-ray diffraction peak intensities and crystallite 
sizes of the Biofield Energy Treated magnesium were decreased ranging from $0.72 \%$ to $11.43 \%$ and $3.81 \%$ to $19.40 \%$, respectively, compared to the control sample. The average crystallite size of the Biofield Energy Treated magnesium was significantly reduced by $13.39 \%$, compared to the control sample. These altered crystalline properties of the Biofield Energy Treated magnesium might be due to the possible formation of new polymorph after the Biofield Energy Treatment. Such polymorph might help in improving the solubility and bioavailability of the Biofield Energy Treated magnesium as compared to the control sample. The total weight loss of the Biofield Energy Treated magnesium was increased by 79.09\% during the thermal degradation; however, the residue amount was decreased by $40.31 \%$ as compared to the control sample. Thus, the thermal data indicated the increased thermal degradation of the Biofield Energy Treated magnesium compared with the control sample. The overall results revealed that the Trivedi Effect ${ }^{\circledR}$-Consciousness Energy Healing Treatment has significantly altered the physicochemical and thermal properties of the magnesium sample that might alter the solubility, appearance, flowability, bioavailability, and thermal stability of the treated magnesium compared with the control sample. Therefore, the novel approach of using the Biofield Energy Treated magnesium in the nutraceutical/pharmaceutical formulation could be beneficial in the treatment of various diseases such as vitamin D deficiency borne rickets and osteoporosis, muscle cramps and spasm, gestational deficiency in pregnancy, migraine, kidney disease, diabetes, and heart diseases, etc.

\section{Acknowledgement}

The authors are grateful to Central Leather Research Institute, SIPRA Lab. Ltd., Trivedi Science, Trivedi Global, Inc., Trivedi Testimonials, and Trivedi Master Wellness for their assistance and support during this work.

\section{References}

1. Gums JG (1987) Clinical significance of magnesium: a review. Drug Intell Clin Pharm 21(3): 240-246.

2. C Lo (2000) Integrating nutrition as a theme throughout the medical school curriculum. Am J Clin Nutr 72 (3 Suppl): 882S-889S.

3. Fawcett WJ, Haxby EJ, Male DA (1999) Magnesium: Physiology and pharmacology. Br J Anaesth 83(2): 302-320.

4. Elin RJ (2010) Assessment of magnesium status for diagnosis and therapy. Magnesium Res 23: S194-S198.

5. Kubota T, Shindo Y, Tokuno K, Komatsu H, Ogawa H, et al. (2005) Mitochondria are intracellular magnesium stores: investigation by simultaneous fluorescent imagings in PC12 cells. Biochim Biophys Acta 1744(1): 19-28.

6. Song WJ, Chang YS (2012) Magnesium sulfate for acute asthma in adults: a systematic literature review. Asia Pac Allergy 2(1): 76-85.

7. Colice GL (2013) Comparative effectiveness of intravenous and inhaled magnesium in acute asthma. J Comp Eff Res 2(5): 437-441.

8. Medalle R, Waterhouse C, Hahn TJ (1976) Vitamin D resistance in magnesium deficiency. Am J Clin Nutr 29(8): 854-858.

9. Young GL, Jewell D (2002) Interventions for leg cramps in pregnancy. Cochrane Database Syst Rev 11(8): 1CD000121.
10. Makrides M, Crosby DD, Bain E, Crowther CA (2014) Magnesium supplementation in pregnancy. Cochrane Database Syst Rev 3(4): CD000937.

11. Rudnicki M, Frolich A, Rasmussen WF, McNair P (1991) The effect of magnesium on maternal blood pressure in pregnancy-induced hypertension a randomized double-blind placebo-controlled trial. Acta Obstet Gynecol Scand 70(6): 445-450.

12. Peikert A, Wilimzig C, Köhne-Volland R (1996) Prophylaxis of migraine with oral magnesium: results from a prospective, multi-center, placebocontrolled and double-blind randomized study. Cephalalgia 16(4): 257263.

13. Veronese N, Fernando WS, Luchini C, Solmi M, Sartore G, et al. (2016) Effect of magnesium supplementation on glucose metabolism in people with or at risk of diabetes: A systematic review and meta-analysis of double-blind randomized controlled trials. Eur J Clin Nutr 70(12): 13541359.

14. Derom ML, Sayón OC, Martínez OM, Martínez GMA (2013) Magnesium and depression: A systematic review. Nutr Neurosci 16(5): 191-206.

15. Schwalfenberg GK, Genuis SJ (2017) The importance of magnesium in clinical healthcare. Scientifica (Cairo) 2017: 4179326.

16. Trivedi MK, Branton A, Trivedi D, Nayak G, Panda P, et al. (2016) Evaluation of the isotopic abundance ratio in biofield energy treated resorcinol using gas chromatography-mass spectrometry technique. Pharm Anal Acta 7(5): 481.

17. Trivedi MK, Branton A, Trivedi D, Nayak G, Bairwa K, et al. (2015) Spectroscopic characterization of disodium hydrogen orthophosphate and sodium nitrate after biofield treatment. J Chromatogr Sep Tech 6: 282.

18. Berman JD, Straus SE (2004) Implementing a research agenda for complementary and alternative medicine. Annu Rev Med 55: 239-254.

19. Barnes PM, Bloom B, Nahin RL (2008) Complementary and alternative medicine use among adults and children: United States, 2007. Natl Health Stat Report 10(12): 1-23.

20. Trivedi MK, Branton A, Trivedi D, Nayak G, Gangwar M, et al. (2015) Agronomic characteristics, growth analysis, and yield response of biofield treated mustard, cowpea, horse gram, and groundnuts. International Journal of Genetics and Genomics 3: 74-80.

21. Trivedi MK, Branton A, Trivedi D, Nayak G, Mondal SC, et al. (2015) Evaluation of plant growth, yield and yield attributes of biofield energy treated mustard (Brassica juncea) and chickpea (Cicer arietinum) seeds. Agriculture, Forestry and Fisheries. 4: 291-295.

22. Trivedi MK, Branton A, Trivedi D, Nayak G, Charan S, et al. (2015) Phenotyping and 16S rDNA analysis after biofield treatment on Citrobacter braakii: A urinary pathogen. J Clin Med Genom 3: 129.

23. Trivedi MK, Patil S, Shettigar H, Mondal SC, Jana S (2015) Evaluation of biofield modality on viral load of Hepatitis B and C viruses. Journal of Antivirals \& Antiretrovirals 7(3): 83-88.

24. Trivedi MK, Patil S, Shettigar H, Mondal SC, Jana S (2015) An impact of biofield treatment: Antimycobacterial susceptibility potential using BACTEC 460/MGIT-TB System. Mycobact Dis 5: 189.

25. Trivedi MK, Patil S, Shettigar H, Bairwa K, Jana S (2015) Effect of biofield treatment on spectral properties of paracetamol and piroxicam. ChemSci J 6: 98.

26. Trivedi MK, Tallapragada RM, Branton A, Trivedi D, Nayak G, et al. (2015) Potential impact of biofield treatment on atomic and physical characteristics of magnesium. Vitam Miner 3: 129.

27. Trivedi MK, Branton A, Trivedi D, Nayak G, Plikerd WD, et al. (2017) A Systematic study of the biofield energy healing treatment on physicochemical, thermal, structural, and behavioral properties of magnesium gluconate. International Journal of Bioorganic Chemistry 2(1): $135-145$. 
28. Trivedi MK, Patil S, Tallapragada RM (2013) Effect of biofield treatment on the physical and thermal characteristics of vanadium pentoxide powders. J Material SciEng S 11: 001.

29. Trivedi MK, Branton A, Trivedi D, Nayak G, Sethi KK, et al. (2016) Gas chromatography-mass spectrometry based isotopic abundance ratio analysis of biofield energy treated methyl-2-napthylether (Nerolin). American Journal of Physical Chemistry 5(4): 80-86.

30. Trivedi MK, Tallapragada RM, Branton A, Trivedi D, Nayak G, et al. (2015) Characterization of physical and structural properties of aluminum carbide powder: Impact of biofield treatment. J Aeronaut Aerospace Eng $4: 142$.

31. Trivedi MK, Patil S, Shettigar H, Bairwa K, Jana S (2015) Phenotypic and biotypic characterization of Klebsiella oxytoca: An impact of biofield treatment. J MicrobBiochemTechnol 7: 203-206.

32. Nayak G, Altekar N (2015) Effect of biofield treatment on plant growth and adaptation. J Environ Health Sci 1: 1-9.

33. Singh J, Trivedi MK, Branton A, Trivedi D, Nayak G, et al. (2017) Consciousness energy healing treatment based herbomineral formulation: A safe and effective approach for skin health. American Journal of Pharmacology and Phytotherapy 2(1): 1-10.

34. Smith DM, Trivedi MK, Branton A, Trivedi D, Nayak G, et al. (2017) Skin protective activity of consciousness energy healing treatment based herbomineral formulation. Journal of Food and Nutrition Sciences 5(3): 86-95.

35. Koster DA, Trivedi MK, Branton A, Trivedi D, Nayak G, et al. (2018) Evaluation of biofield energy treated vitamin $D_{3}$ on bone health parameters in human bone osteosarcoma cells (MG-63). Biochemistry and Molecular Biology 3(1): 6-14.

36. Trivedi MK, Patil S, Shettigar H, Gangwar M, Jana S (2015) In vitro evaluation of biofield treatment on cancer biomarkers involved in endometrial and prostate cancer cell lines. J Cancer SciTher 7: 253-257.

37. Trivedi MK, Sethi KK, Panda P, Jana S (2017) A comprehensive physicochemical, thermal, and spectroscopic characterization of zinc (II) chloride using X-ray diffraction, particle size distribution, differential scanning calorimetry, thermogravimetric analysis/ differential thermogravimetric analysis, ultraviolet-visible, and Fourier transform-infrared spectroscopy. International Journal of Pharmaceutical Investigation 7(1): 33-40.
38. Trivedi MK, Sethi KK, Panda P, Jana S (2017) Physicochemical, thermal and spectroscopic characterization of sodium selenate using XRD, PSD, DSC, TGA/DTG, UV-vis, and FT-IR. Marmara Pharmaceutical Journal 21(2): 311-318.

39. Desktop x-ray diffractometer "Miniflex"”. The Rigaku Journal 14: 29-36 1997.

40. Zhang T, Paluch K, Scalabrino G, Frankish N, Healy AM, et al. (2015) Molecular structure studies of (1S,2S)-2-benzyl-2,3-dihydro-2(1Hinden-2-yl)-1H-inden-1-ol. J Mol Struct 1083: 286-299.

41. Langford JI, Wilson AJC (1978) Scherrer after sixty years: A survey and some new results in the determination of crystallite size. J Appl Cryst 11: $102-113$.

42. Trivedi MK, Branton A, Trivedi D, Nayak G, Plikerd WD, et al. (2017) A systematic study of the biofield energy healing treatment on physicochemical, thermal, structural, and behavioral properties of iron sulphate. International Journal of Bioorganic Chemistry 2: 135-145.

43. Katayama M (1956) The crystal structure of an unstable form of chloroacetamide. Acta Crystallogr 9: 986-991.

44. Rashidi AM, Amadeh A (2009) The effect of saccharin addition and bath temperature on the grain size of nanocrystalline nickel coatings. Surf Coat Technol 204(3): 353-358.

45. Buckton G, Beezer AE (1992) The relationship between particle size and solubility. Int J Pharmaceutics 82(3): R7-R10.

46. Mosharrof M, Nystrom C (1995) The effect of particle size and shape on the surface specific dissolution rate of microsized practically insoluble drugs. Int J Pharm 122(1-2): 35-47.

47. Trivedi MK, Branton A, Trivedi D, Nayak G, Lee AC, et al. (2017) Evaluation of the impact of biofield energy healing treatment (the Trivedi Effect ${ }^{\circledR}$ ) on the physicochemical, thermal, structural, and behavioral properties of magnesium gluconate. International Journal of Nutrition and Food Sciences 6: 71-82.

48. Savjani KT, Gajjar AK, Savjani JK (2012) Drug solubility: Imrtance and enhancement techniques. ISRN Pharmaceutics, 2012: Article ID 195727. 